\section{Price Stability and the Efficiency of the Retail Payments System}

\section{William R. Emmons}

teror

wo of the Federal Reserve's most important policy mandates are to foster price stability and to overseethe integrity and efficiency of the payments system. Effective price stability is usually defined as annual rates of inflation or deflation close to zero. The integrity and efficiency of the payments system, on the other hand, are related to the reliability and cost effectiveness of the institutions and practices that individuals, businesses, and government entities use to transfer funds to one another. Although these policy goals are seldom discussed together, this article illustrates how pricestability could enhance the efficiency of the payments system. The argument is reminiscent of and extends Friedman's (1969) analysis of the optimum quantity of money.

To simplify the discussion, I focus only on the efficiency-enhancing effects of price stability on the retail payments system, which consists of all those transfers of funds that involve individuals, nonbank firms, and government entities. ${ }^{1}$ It is quite likely that the integrity (that is, reliability) of the payments system would be increased as a result of the greater financial stability that would accompany stable prices, but I do not consider that issue here.

The key link between price stability and the efficiency of the retail payments system is the level of nominal short-term interest rates. This is because the benefit of float to the user of a payment instrument- that is, the interest that can be earned while a payment order is in the process of clearing but has not yet been settled-is proportional to the prevailing interest rate as follows:

User F loat Benefit $=($ Payment Amount $) \times$ (Days Spent in Clearing) $x$ (Daily Interest Rate on Investable Funds)

Price stability would almost certainly result in relatively low nominal short-term interest rates because nominal interest rates and inflation have historically moved up and down together (see Figure 1). Thus float benefits would be relatively small with stable prices.

Why does float reduce the efficiency of the payments system? A policymaker might be tempted to ignore float because it causes a pure transfer to occur. That is, the interest earnings gained by one party correspond to losses of interest income by the payment counterparty (or counterparties). The parties to any transaction involving float could in principle negotiate a contract that compensates the loser(s) so that no intervention would be necessary.

The actual net result of float is far from benign, however, because it encourages the use of float-intensive payment instruments instead of other instruments that generate less float. N egotiation to allocate the costs and ben efits of various payment methods and instruments is difficult because there are typically more than two parties to every transaction, involving not just the parties making and receiving payment, but also the primary payment provider and potentially several other intermediaries in the payment-clearance and payment-settlement chains. Although payment providers and other intermediaries (primarily banks) or receivers (such as merchants) could levy fees or penalties to discourage the use of particular payment instruments, this practice is not widespread. Instead, originators of payments in

\footnotetext{
${ }^{1}$ Funds transfers that occur strictly among banks are termed wholesale payments. I do not discuss the wholesale payments system in this article.
} 
Figure 1

Inflation and Interest Rates, 1960-95

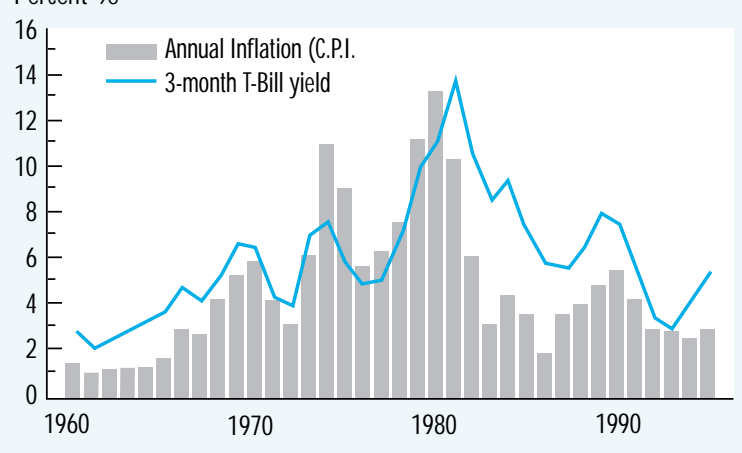

2 Float benefits have dedined in recent years due to generally lower nominal interest rates and faster collection of checks. Recent survey evidence indicates that float still plays a role in payment-instrument choice for at least some consumers and businesses, however. For example, 8 percent of creditcard users cite " 30 days to pay" as their primary reason for using their cards (University of Michigan, 1995). Fifteen percent of surveyed businesses cited concerns about the loss of float as the reason that their companies had chosen not to use financial electronic data interchange (E.D.I.) as a means of payment, even though E.D.I. may generate significant cost savings in other ways (Knudson, Walton, and Young, 1994, p. 275).

3 See Humphrey and Berger (1990), Table 2-A2, p. 82, note f, or the Appendix to this article, note $c$.

${ }^{4}$ Humphrey and Berger (1990, p.49) define total social or real resource costs of payment instruments as the sum of (1) production costs, which include costs of fabricating and distributing the physical payment instruments, and (2) processing costs, including the costs of accepting, safeguarding, and the United States generally retain some control over the choice of payment method and do not usually face an explicit price penalty when choosing riskier or costlier payment methods. Therefore, the net user costs of alternative payment instruments, including float benefits, are potentially important in determining actual payment practices. ${ }^{2}$

Float-influenced choice of payment instruments is inefficient for at least two reasons. First, float is an imperfectly priced loan (sometimes unpriced), and it therefore increases the riskiness of the payments system. For example, a merchant who accepts a check in payment is actually extending credit to the customer. The merchant's loan is repaid not when the merchant deposits the customer's check, but (typically) a few days later when the merchant's bank makes the funds available for withdrawal. Bad checks (those written against insufficient funds in the customer's account) represent less than nine-tenths of one percent of all checks written, but a typical merchant is ill-suited to judging the credit risks presented by any given customer. ${ }^{3}$ Thus although accurate pricing of credit is essential to prevent concentrations of risk and potential disruptions to the payments system, checks in fact generate a substantial volume of mispriced credit in the form of float.

This article focuses on a second reason why float is harmful. Available empirical evidence on the relative cost efficiency of the various retail payment methods in use today reveals that the most float-intensive payment methods are also typically the most costly to produce and process in terms of economic resources used-namely capital, labor, and land. ${ }^{4}$ The most important examples in the United States of float-intensive and cost-inefficient retail payment instruments are checks and credit cards, which are the most frequently used retail payment methods after cash. Thus a systematic preference for float-intensive payment instruments by originators of payments and an unwillingness or inability of other parties to discourage it reduce overall payments-system efficiency.

The correlation between user float benefits and real-resource costs is not surprising when one considers that both are a reflection of a relatively long and often complex sequence of processing stages, many of them labor intensive. Checks, in particular, may require several rounds of processing because several banks may be involved and virtually every check is physically returned to the bank whose customer wrote it, wherever that may be.

Clearly, float is not the only impetus for excessive use of costly retail payment instruments in the United States. In addition to the forementioned fact that actual costs are often not fully passed through to the party controlling the choice of instrument, thus encouraging overuse, checks and credit cards provide users with purchasing flexibility in the form of ready access to short-term credit, as well as a familiar and trusted system for keeping records of transactions. These practices and features reflect the outcome of a competitive market for financial services, so there is little basis for direct policy intervention to change retail payment practices, even though they do not seem to be the most efficient use of economic resources. Hence a monetary policy geared toward price stability and the reduction of float incentives to choose particular payment instruments is a potentially important way for the Federal Reserve to fulfill its mandate of enhancing the efficiency of the payments system. 
This article begins with a description of the current U.S. retail payments system, paying particular attention to the float intensity and cost efficiency of the various payment instruments (section 1). Section 2 explores the role of float in the retail payments system. A series of examples illustrates that price stability and low nominal interest rates could in some circumstances improve the cost efficiency of the U.S. retail payments system by reducing users' incentives to choose float-intensive payment instruments. The third section considers whether float incentives are large enough to be considered economically significant. Section 4 concludes.

\section{THE U.S. RETAIL PAYMENTS SYSTEM}

The most recent comprehensive empirical examination of the U.S. retail payments system was carried out by David B. Humphrey and Allen N. Berger (1990), using data for 1987. According to Humphrey and Berger, American consumers, businesses, and government entities made about 334 billion payments for goods, services, and financial transactions in 1987, representing a total transfer of funds of about $\$ 342$ trillion. Since gross domestic product (GDP) in 1987 was $\$ 4.69$ trillion, it follows that the annual volume of payments was about 73 times as large as GDP. If that same ratio prevailed in 1995, the total value of payments in the U.S. economy would have been $\$ 528$ trillion, or about $\$ 2$ million per U.S. resident. Although much of this turnover occurs in the wholesale payments system in association with financial markets, the basic economic fact remains that large amounts of payments are associated with producing output and earning income in an advanced economy.

The retail share of total payment activity - that is, all transactions except those strictly between banks-is about 99 percent when measured by number of transactions and about 18 percent when measured by the dollar volume of transfers. The precise breakdown of retail payments activity by instrument is very difficult to estimate. Humphrey and Berger concluded that, for 1987, approximately 279 billion transactions, or 83.5 percent of retail payments, were made in cash (that is, currency or coin). Another 52 billion, or 15.7 percent, were check or credit card transactions. ${ }^{5}$ The remaining eight-tenths of one percent of retail payments were completed with a variety of instruments, including debit cards, travel er's checks, money orders, automated clearinghouse $(\mathrm{ACH})$ transfers, wire transfers, point-ofsale (POS) electronic transfers, financial electronic data interchange (EDI), electronic benefit transfers (EBTs), automated teller machines (ATMs), home banking by telephone or computer, Internet-based cybercash, and stored-value cards. Wholesale (interbank) payment transactions, which account for the bulk of the dollar volume in the U.S. payments system, are carried out using wire transfers, ACHs and, to a limited extent, the exchange of paper-based instruments such as checks and credit card receivables.

A recent survey of consumers found a much smaller role for cash in retail payments and correspondingly larger roles for noncash payment instruments (U niversity of Michigan, 1995). The survey, conducted on behalf of the Federal Reserve System, found that cash accounted for only 60 percent of consumer transactions, whereas checks accounted for 30 percent, credit cards for 8 percent, and debit cards for 2 percent in mid-1995. All other forms of payment accounted for less than 1 percent of transactions.

Although retail payment practices may indeed have changed substantially since 1987, the extent of the decline in cash's importance, estimated in this survey, may be overstated. Most important, undersampling of certain groups in the population is likely to exert a downward bias on the estimated share of cash in total transactions. Participants in the underground economy are likely to be underrepresented in the sample, as are individuals who do not maintain banking relationships. Members of these groups rely to a great degree (or exclusively) on cash for making payments transmitting payment instruments for purposes of collecting good funds from the payor. Both production and processing costs ultimately entail outlays for capital, labor, and land or buildings.

${ }^{5}$ See Humphrey and Berger (1990, p. 77). Virtually all transactions made by cash, check, or credit card are retail payments as defined here. Checks and credit cards accounted for 14.2 percent and 1.5 percent of retail payments, respectively. 
6 Humphrey and Berger (1990, pp. 80- 5. See also the Appendix.) estimated that total (gross) floatbenefits were about $\$ 55$ billion in the U.S. payments system in 1987, whereas GDP was $\$ 4.69$ trillion. To arrive at this estimate for float benefits, Humphrey and Berger estimated the amount of all payments made and the length of time each type of payment spent in clearing, then multiplied these amounts by the average yield on three-month T-bills during 1987, which was 5.775 percent.

7 See Humphrey, Pulley, and Vesala (1996, p. 915). For the United States in 1995, this implies a cost of between \$147 billion and \$221 billion.

8 See Humphrey and Berger (1990, pp. 77- 9, 80-5). Also see the Appendix.

${ }^{9}$ Payment finality refers to completion of an economic exchange with no recourse by either party, except in case of fraud. Finality contrasts with provisionality, as when a check is presented in payment. When payment is provisional, the transaction may still be reversed within a certain period if, for example, the checkwriter has insufficient funds in the deposit account to cover the payment.

${ }^{10}$ See Humphrey and Berger (1990, pp. 80- 5). Also see the Appendix.

${ }^{11}$ See Humphrey and Berger (1990, pp. 53-4, 80- 5, and 86).

12 See Humphrey and Berger (1990, p. 54). and are notoriously difficult to reach and to interview. The estimates in Humphrey and Berger may be more reliable because they do not rely solely on consumer survey data. Instead, they construct estimates of cash usage by combining consumer, retail, and financial-institution data. The Appendix contains details on Humphrey and Berger's methodology.

\section{Traditional Retail Payment Methods: Cash, Checks, and Credit Cards}

Float benefits run into the tens of billions of dollars in the United States each year and have been equival ent to about 1 percent of GDP in recent years. ${ }^{6}$ The real-resource cost to society of making payments is also quite large, accounting for between 2 percent and 3 percent of national product annually. ${ }^{7}$ The Appendix to this article reproduces Humphrey and Berger's (1990) Table 2-A2 in slightly abridged form, providing details concerning the resource costs and float benefits associated with various payment instruments.

The three most commonly used retail payment instruments-cash, checks, and credit cards-generated essentially all of the float and consumed 93 percent of all the real resources devoted to making payments in the United States in 1987. These same instruments accounted for 99 percent of transactions and 18 percent of the funds transferred in that year. ${ }^{8}$ Thus efforts to reduce the market share of these traditional instruments, to increase the efficiency of these instruments, or both-especially with regard to checks and credit cards-could produce significant economic benefits.

Cash is currently the predominant and most efficient instrument for making payments in the vast majority of face-to-face retail transactions. Cash provides simplicity, anonymity, and finality to both buyer and seller at very low cost. ${ }^{9}$ The average social cost of using cash in retail payments amounted to approximately $\$ 0.04$ per transaction as of $1987 .{ }^{10} \mathrm{In}$ addition to the risk of loss or theft, one major disadvantage of cash from the user's point of view is that it entails a float cost (corresponding to interest earned by cash's issuer, the government) because cash balances in one's wallet or purse earn no interest. Milton Friedman (1969) stressed that positive float costs borne by users of cash drive a wedge between individual and social optimality because individuals and firms will hold smaller cash balances than otherwise and will expend real resources to compensate for their inefficiently reduced holdings of money.

Despite the attractive combination of attributes provided by cash for many retail transactions, consumers have, over the years, adopted alternative payment methods to varying degrees for specific purposes, such as payment by mail or over the telephone. The most familiar substitute for cash in retail payments in the United States is the paper check, which represents a consumer's IOU backed by the funds in his or her bank deposit account. Checks are sometimes preferred to cash because they are more secure (requiring endorsement by the writer and the receiver), because they are more flexible (just as easily written for $\$ 1$ or $\$ 999.99$, given sufficient deposit funds), and because they provide a convenient written record of transactions (summarized in the monthly account statement prepared by the consumer's bank, as well as in the form of the cancelled and returned checks themselves).

Checks also provide the writer a float benefit that varies with the prevailing interest rate, the check amount, and the time a given check spends in the mail, in the recipient's cash box, and in the interbank collection and clearing process. Estimates for 1987 indicated that consumer checks were outstanding (that is, generating float) for an average of three days, whereas checks written by businesses or government entities remained outstanding for five days. Average float benefits for all types of checks combined were $\$ 0.83$ per check. ${ }^{11}$ Businesses captured the largest float benefits- $\$ 35$ billion in 1987because they tend to write larger checks that remain outstanding for more days. Consumer float benefits from checks were small- $\$ 2$ billion - with government float benefits falling near the average for all 
checks, about $\$ 2$ billion. ${ }^{12}$ Checks and their associated processing infrastructure are quite costly, consuming approximately $\$ 0.79$ of economic resources for every check written in 1987. ${ }^{13}$

Another substitute for cash (and checks) is the credit card. Bank-issued credit cards are sometimes co-branded, an arrangement that allows nonbank firms to participate in the marketing of the card and to deliver special benefits or promotions to cardholders. Credit cards, like checks, provide the accepting merchant with an IOU that can be redeemed for cash or deposits at the merchant's bank. In practice, credit cards provide consumers with most of the advantages of checks, along with greater on-the-spot purchasing power. This advantage derives primarily from the assumption of nonpayment risk by the card-issuing bank. The acceptance of liability differs from the case of a check, in which the merchant bears the risk that the check cannot be redeemed for cash or deposits. Banks are willing to absolve merchants of this risk when credit cards are used because banks specialize in screening and monitoring retail customers' creditworthiness and because merchants effectively pay a fee for each credit card transaction they accept. ${ }^{14}$

The risks to banks involved in credit card transactions are minimized by screening the creditworthiness of consumers both before they receive cards and at the time of a purchase. Credit checks before a card is issued allow issuing banks to exclude likely defaulters from using their card at all. On-line data bases maintained by the major credit card associations allow merchants to obtain an update on a consumer's credit status at the time of purchase. Merchants receive an authorization number from the issuing bank at the time of purchase to verify the credit check and thereby transfer nonpayment risk to the bank.

Credit cards provide a significant amount of float if they are used exclusively as payment instruments. This is true of socalled convenience users of credit cards, those cardholders who pay off all charges within the grace period granted by the issuer. Use of the card as an instrument for taking out preapproved consumer loans, on the other hand (that is, running a balance), redirects the float benefit from the consumer to the issuing bank. Float benefits averaged about $\$ 0.44$ per credit card transaction in 1987, considerably more than the estimated $\$ 0.07$ of float benefit per check written by consumers or the $\$ 0.05$ of float cost per cash transaction. ${ }^{15}$ Credit card payments are, like checks, relatively costly to process because they require a complex supporting infrastructure and multiple rounds of processing by the parties seeking to collect the ultimate payment in bank funds. Humphrey and Berger estimate that the average credit card payment consumes about $\$ 0.88$ in economic resources. ${ }^{16}$

\section{Non-traditional Retail Payment Methods: ACH, Debit Cards, and Stored-Value Cards}

Although the majority of U.S. consumers and businesses express satisfaction with their traditional payment options (cash, checks, and credit cards), significant efforts are currently being made by many nonfinancial firms, banks, trade associations, and government agencies such as the Federal Reserve to expand the use of newer retail payment methods. In many instances, the technology underlying the newer payment methods has existed for some time, although it has not been in common use. In other cases, advances in information technology and communications have accelerated the development of these substitutes for cash, checks, and credit cards.

$\mathrm{N}$ ew methods of making consumer payments include ACHs, debit cards, ATM cards, stored-value cards, and cybercash, a payment instrument that exists on, and is used solely to make purchases over, computer networks. New methods for making business and government payments include $A C H$, financial EDI, purchasing cards, and EBT.

Among the most important of the newer retail-payment methods is the use of automated clearinghouses. ACH transfers are used to effect direct deposit of pay-
${ }^{13}$ See Humphrey and Berger (1990, pp. 80-5). See the Appendix.

${ }^{14}$ The credit card fee is collected by the merchant's bank by discounting the merchant's credit card receipts. For example, the merchant trades a credit card charge receipt of $\$ 100$ for a $\$ 97$ credit in its account at the bank. The merchant's bank then collects the receivable from the card-issuing bank through established interbank clearing channels, receiving perhaps $\$ 98$ for the item. Finally, the issuing bank bills the cardholder periodically, for payment of the full $\$ 100$ and the accumulated balance of other charges.

${ }^{15}$ See Humphrey and Berger (1990, pp. 50, 54, and 80- 5). See the Appendix.

${ }^{16}$ See Humphrey and Berger (1990, pp. 80-5). See the Appendix. 
checks, Social Security checks, or other benefits into recipients' bank accounts; to carry out routine repetitive payments by consumers, such as mortgage payments, insurance premiums or utility bills; or to execute cash-management operations for far-flung businesses. Tiny amounts of float are created in $\mathrm{ACH}$ debit transfers (requests for payment), whereas $\mathrm{ACH}$ credit transfers (sending payments) create no float. Funds transfers made by $\mathrm{ACH}$ are currently very efficient because they exploit economies of scale in information processing. A large employer can pay its employees, for example, simply by encoding all of the pertinent payroll information (including the employee's name, the amount of the payment, and the employee's bank account number) and sending this information to the $\mathrm{ACH}$ through its bank (typically on magnetic tape or through EDI). The funds transfers from the employer's account to those of all its employees are then carried out electronically among banks at a precisely specified time. Humphrey and Berger (1990) estimate that the average social cost of an $\mathrm{ACH}$ transfer was only $\$ 0.29$ as of 1987 . As more and more transactions occur through the $\mathrm{ACH}$, the cost per transaction falls, an indication that unexploited economies of scale remain in ACH payments. ${ }^{17}$

Another fast-growing form of retail payment is the debit card, sometimes also called a POS card. To consumers, a debit card functions much like a credit card at the point of purchase, with one important exception. Rather than providing the consumer with float, as with convenience use of a credit card, a debit card transaction transfers funds directly from the consumer's bank account to the retailer's bank account. Hence consumers receive no float benefits..$^{18}$ The lack of float associated with debit cards is almost certainly one of the reasons why consumers have not adopted debit cards even more rapidly than they have. Debit card payment systems are developing rapidly, so it is difficult to know how costefficient they are currently. Estimates from the late 1980s put debit card transaction costs at about $\$ 0.47$ per transaction, consid- erably less than the transaction costs of credit cards and checks, but greater than those for cash and $\mathrm{ACH} .{ }^{19}$

A new form of retail payment that has captured the attention of many merchants, bankers, and computer experts is the stored-value card, also referred to as the electronic purse or electronic cash. Storedvalue cards promise greater convenience in certain retail-purchase situations, including those in which coins are normally used. For example, stored-value cards would be quite convenient for making purchases from vending machines, at newspaper kiosks, or in laundromats. Stored-value cards can be thought of as small-dollar traveler's checks. The consumer purchases a card from a financial institution with monetary value encoded on the card and then uses it anywhere merchants are willing to accept its stored value in payment. The merchant, in turn, trades the stored value for monetary value in the merchant's bank account. Finally, the bank must collect funds from the card-issuing institution. Stored-value cards will likely suffer in consumers' eyes because they incur a float cost: Consumers must pay out funds in advance of any retail purchases, so the funds do not earn interest.

Given the recent arrival of stored-value cards on the retail payment scene, it is impossible to gauge their cost effectiveness with any certainty. One relevant comparison might be the resource costs associated with traveler's checks, which were estimated by Humphrey and Berger (1990) to be about $\$ 1.18$ per transaction. The purely electronic nature of stored-value cards should reduce the per-unit costs to a great extent relative to traveler's checks, but the necessary investments by merchants, banks, and consumers to support the cards means that the economics of stored-value cards will not be favorable until a substantial volume of payment activity is ensured.

In sum, there has been moderate progress in converting U.S. retail payments from a paper-based system to a more predominantly electronic system. The Appendix summarizes the resource costs and user float benefits associated with the major retail payment instruments as of Appendix. 
Table 1

Use of Non-Cash Retail Payment Instruments (in Billions*)

\begin{tabular}{|c|c|c|c|c|c|c|c|}
\hline & 1988 & 1989 & 1990 & 1991 & 1992 & 1993 & 1994 \\
\hline Checks & 50.99 & 52.90 & 55.44 & 57.47 & 58.40 & 60.30 & 61.67 \\
\hline Credit Cards & 8.81 & 8.90 & 10.75 & 11.24 & 11.70 & 12.52 & 13.68 \\
\hline $\mathrm{ACH}$ & 1.01 & 1.18 & 1.43 & 1.63 & 1.84 & 2.09 & 2.37 \\
\hline Debit Cards & 0.17 & 0.22 & 0.28 & 0.30 & 0.51 & N.A. & 1.05 \\
\hline Total (including instruments not shown) & 61.08 & 63.30 & 67.96 & 70.75 & 72.56 & 75.01 & 78.89 \\
\hline
\end{tabular}

* From: Bank for International Settlements (1993, p. 472; 1994, p. 110; and 1995, p. 110)

1987. Cash, check, and credit card processing have become more automated since 1987, thereby reducing unit costs associated with these instruments. At the same time, newer payment instruments have achieved ever-larger transaction volumes, reducing their unit costs.

Purely electronic payment methods, such as debit cards, ACHs, cybercash, and home banking, are among the fastest growing sectors of the payments market and may have accounted for well over 3 billion transactions in 1995. ${ }^{20}$ Table 1 shows the relative importance of several leading noncash retail payment instruments in recent years. Figure 2 illustrates the relatively high growth rates of debit cards and $\mathrm{ACH}$ in particular.

Despite rapid growth of nontraditional retail payment instruments, it is still much too early to describe the changes in U.S. consumers', businesses', and government entities' payment habits to date as a true revolution. After all, it is likely that 60 percent to 80 percent of retail payments are still made in cash and that 15 percent to 30 percent are made with checks or credit cards. ${ }^{21}$ All other payment instruments together probably account for 10 percent of all transactions or less. Hence the retail payments revolution has just begun.

\section{THE ROLE OF FLOAT ON CONSUMER INCENTIVES IN RETAIL PAYMENTS}

This article's theme is that a movement away from today's environment of moderate inflation to one characterized by

\section{Figure 2}

\section{Total Growth in Use of Non-Cash Payment} Instruments 1988-1994

Percent $(\%)$

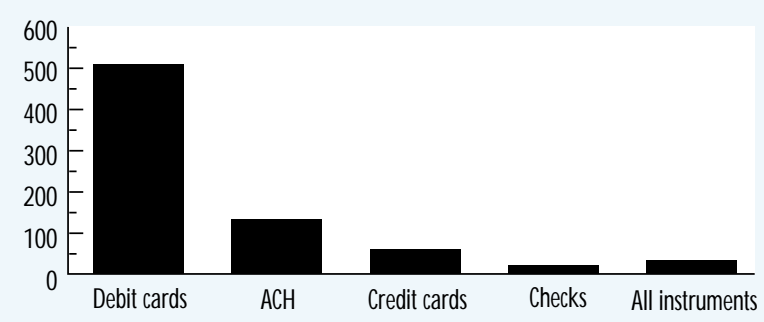

effective price stability could make the retail payments system more efficient. The reason is that, with no sustained inflation and thus consistently low short-term nominal interest rates (averaging perhaps 2 percent to 3 percent), the benefits of float that create incentives for payment originators to choose float-intensive instruments would be much less than they are today. Modest inducements from retailers and payment providers to use the more efficient retail payment instruments, such as merchant surcharges on checks and credit cards or discounts for cash and debit cards, might then be effective in changing payment practices. Although payment-instrument choice would be most efficient if each instrument's actual resource cost were passed through to the party choosing the instrument-typically the party making payment-even partial pass-through of costs would be more effective in an environment of price stability. Thus this article extends Friedman's (1969) analysis of the welfare costs of in-

\footnotetext{
20 See Bank for International Settlements (1993, p. 472; 1994, p. 110; 1995, p. 110).

${ }^{21}$ See note 20, Humphrey and Berger (1990, pp. 77-9), and University of Michigan (1995).
} 


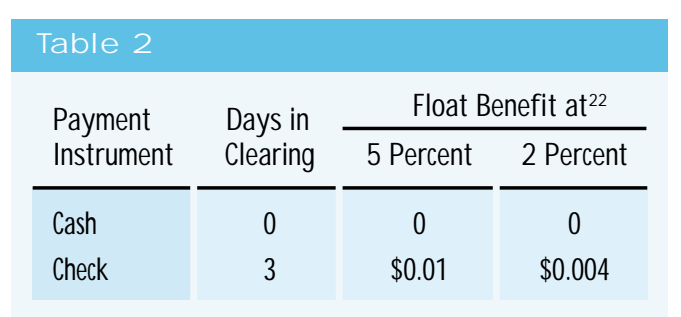

$\begin{array}{lc}\text { Table } 3 & \\ \text { Payment Instrument } & \frac{\begin{array}{c}\text { Average Social Cost } \\ \text { (in 1995 Prices) }\end{array}}{\text { Cash }} \\ \text { Check } & \$ 0.05 \\ & \$ 1.06\end{array}$

\begin{tabular}{|c|c|c|c|}
\hline \multirow{2}{*}{$\begin{array}{l}\text { Payment } \\
\text { Instrument }\end{array}$} & \multirow{2}{*}{$\begin{array}{l}\text { Days in } \\
\text { Clearing }\end{array}$} & \multicolumn{2}{|c|}{ Float Benefit at ${ }^{24}$} \\
\hline & & 5 Percent & 2 Percent \\
\hline Debit Card & 0 & 0 & 0 \\
\hline Credit Card & 15 & $\$ 1.23$ & $\$ 0.49$ \\
\hline
\end{tabular}

${ }^{22}$ Float benefit is the amount of the payment, $\$ 25$, multiplied by the number of days the payment takes to clear, multiplied by the daily interest rates- 5 percent or 2 percent divided by 365

${ }^{23}$ These are average rather than marginal social costs, which one would normally prefer when analyzing a given consumer payment decision. The illustrations here are intended to point out the full-cost implications of various payment practices over time, however, so average costs are the relevant measure.

${ }^{24}$ Float benefit is the amount of the payment, $\$ 600$, multiplied by the number of days the payment takes to clear, multiplied by the daily interest rates- 5 percent or 2 percent divided by 365.

\section{Table 5}

\begin{tabular}{lc} 
Payment Instrument & $\begin{array}{c}\text { Average Social Cost } \\
\text { (in 1995 Prices) }\end{array}$ \\
\cline { 1 - 1 } Debit Card & $\$ 0.63$ \\
Credit Card & $\$ 1.18$
\end{tabular}

flation to the full range of retail payment instruments in use today.

To illustrate the role of float and the potential importance of price stability in the retail payments system, I consider three examples. The examples are designed to capture the roles played by float and explicit transactions costs in a small-value personal payment transaction, in a largevalue personal transaction, and in a largevalue business transaction, respectively, in determining which payment instrument a rational decision maker would be likely to choose. First, I determine the incentives the decision maker would face as a result of float. Then I compare the privately optimal choice of payment instrument with the most efficient choice from the standpoint of total social costs. Finally, I examine the

potential of different levels of nominal interest rates and float benefits to affect decision makers' behavior when they bear some or all of the social costs resulting from their decisions.

\section{Example 1: Small-Value Personal Payment} Transaction. A consumer purchases a restaurant meal for $\$ 25$. She may pay with cash or check. Assume first that the only relevant cost to the customer is float; in other words, there are no per-check fees and the customer has at least \$25 in her wallet (hence no need to pay any ATM withdrawal fees). The customer receives no float if she pays with cash, whereas she expects three days of float if paying by check. Which retail payment instrument would she choose if the shortterm interest rate were 5 percent? What if it were 2 percent?

Float benefits associated with each instrument are shown in Table 2 . The rational decision maker prefers to write a check whatever the interest rate, although the float benefit is trivial.

Adjusting Humphrey and Berger's (1990) estimates for 1987 to account for general inflation through 1995, social costs associated with each of the retail payment instruments considered here are shown in Table $3 .{ }^{23} \mathrm{As}$ the table indicates, the customer's choice of a check, though modestly beneficial to herself, is quite costly from the standpoint of overall efficiency of the payments system. In this case, the consumer might switch her payment preference to cash in response to even a small incentive, such as a 1 percent cash discount offered by the restaurant (that is, 25 cents off the bill).

In this example, the potential interest earnings created by float would obviously play a very minor role in a typical decision maker's choice of payment instrument. In fact, this is true of most consumer payments. A more important reason why a consumer might use a check instead of cash is the flexibility it affords. Suppose, for example, that the restaurant diner had no cash in her pocket and no money in her bank deposit account. Suppose further that the customer knew that her pay- 


\begin{tabular}{|c|c|c|c|c|c|}
\hline \multirow{2}{*}{$\begin{array}{l}\text { Payment } \\
\text { Instrument }\end{array}$} & \multicolumn{2}{|c|}{ Float Benefit at } & \multirow{2}{*}{$\begin{array}{l}\text { Average Social Cost and } \\
\text { User Price (1995 Prices) }\end{array}$} & \multicolumn{2}{|c|}{ Total User Benefit at ${ }^{25}$} \\
\hline & 5 Percent & 2 Percent & & 5 Percent & 2 Percent \\
\hline Debit Card & 0 & 0 & $\$ 0.63$ & $-\$ 0.63$ & $-\$ 0.63$ \\
\hline Credit Card & $\$ 1.23$ & $\$ 0.49$ & $\$ 1.18$ & $\$ 0.05$ & $-\$ 0.69$ \\
\hline
\end{tabular}

check would be deposited in her bank account the next day through $\mathrm{ACH}$. Being able to write a check that will not clear for three days can thus be very valuable in some situations. Taking into account the value of flexibility, one can see that the short-term rate may actually understate the true economic value of float.

\section{Example 2: Large-Value Personal Payment} Transaction. Suppose a new homeowner purchases a home appliance, such as a refrigerator, for $\$ 600$. The consumer may pay with a debit to his deposit account using a debit card or with a credit card, both of which the appliance store accepts without surcharge or discount. Assume first that the only relevant cost to the purchaser is float. In other words, there are no transaction fees for either type of payment. The customer receives no float if he pays with his debit card, though he expects 15 days of float if he pays with a credit card. Which payment instrument would a rational decision maker choose if the short-term interest rate were 5 percent? What if it were 2 percent?

Float benefits associated with each instrument are illustrated in Table 4. In this case, it is likely that the consumer would be aware of the benefit of using a credit card to capture float and that he might do so.

Is the customer's choice of payment instrument efficient from the standpoint of the economy's use of resources? Again adjusting Humphrey and Berger's (1990) estimates for 1987 to account for general inflation through 1995, Table 5 shows average social costs associated with the use of debit and credit cards. Comparing the user float benefits to average social costs, one can see that the consumer's personal preferences are again the reverse of the so- cially efficient choice, which would be to use a debit card.

Would full pass-through of the average social cost of the payment instrument change this rational consumer's choice of instrument? It turns out that the answer depends on how much float is available. In an environment such as the one that exists today with a moderate level of inflation and short-term interest rates around 5 percent, the consumer's choice would be unaffected. The situation would be quite different in an environment of price stability and a low interest rate of 2 percent, however. The calculations that a rational decision maker would make if he were forced to pay the full social cost of the payment instrument are shown in Table 6.

One conclusion from the table is striking: Even if a rational consumer were forced to bear the full cost of his choice of payment instrument, he would still choose a credit card if the nominal interest rate were 5 percent, but he would choose a debit card if the interest rate were 2 percent. This example points out that, for at least some retail payment transactions, even the implementation of full passthrough of costs to the purchaser would not eliminate incentives for inefficient payment-instrument choice when float benefits remain substantial. Even with only partial pass-through of costs to payment users, lower interest rates can shift a consumer's incentives in the direction of more efficient payment instruments. The next example illustrates a clear-cut case in which price stability would be likely to have a big effect.

Example 3: Large-Value Business Payment Transaction. Suppose a small-business owner is preparing the firm's monthly payroll covering 10 employees with an average wage payment of $\$ 2,000$ each (that is, a total payroll of
${ }^{25}$ Total user benefit is the user's float benefit at the given interest rate minus the social cost of each payment, which is also the user's price. 


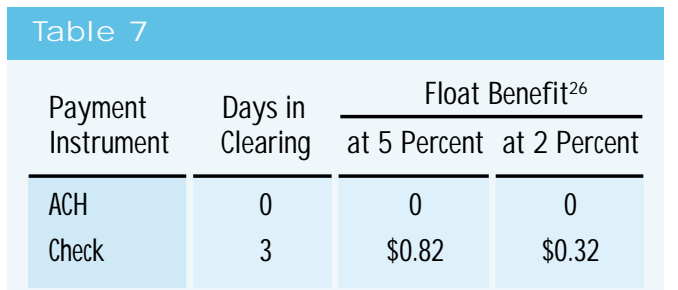

$\begin{array}{lc}\text { Table } 8 \\ \text { Payment Instrument } & \frac{\begin{array}{c}\text { Average Social Cost } \\ \text { (in 1995 Prices) }\end{array}}{\text { ACH }} \\ \text { Check } & \$ 0.39 \\ \$ 1.06\end{array}$

$\$ 20,000)$. The owner may pay her employees using $\mathrm{ACH}$ or checks. First, the owner examines the float implications of the two payment methods. She receives no float if she pays by $\mathrm{ACH}$, whereas she expects three days of float on average if she pays by check. Which method would this rational business owner choose if the short-term interest rate were 5 percent? What if it were 2 percent?

Float opportunity costs per employee are shown in Table 7. Now consider the bank fees associated with each instrument. Assume that the pricing schedule from the owner's bank reflects average social costs exactly. Adjusting Humphrey and Berger's (1990) estimates for 1987 to account for general inflation through 1995, the total bank fees assessed for using each method would be as shown in Table 8. The smallbusiness owner's total costs are therefore shown in Table 9. The net cost of paying her employees is $\$ 0.15$ less per person by check than by $\mathrm{ACH}$ if the interest rate is 5 percent, though the small-business owner saves $\$ 0.35$ per employee by using $\mathrm{ACH}$ under the low-interest rate scenario. This example illustrates that, even if full social costs are passed through to the decision maker, moderate levels of inflation and interest rates-such as we currently have in the United States- may be sufficient to distort incentives toward socially wasteful payment instruments.

To summarize the point made in these examples, the lower the short-term interest rate, the less valuable is a float-intensive payment instrument to the user. With little float benefit available from any payment instrument, originators of payments might shift their payment preferences away from float-intensive instruments, given even a modest inducement to do so. Because the per-item social costs are roughly the same no matter how large the dollar amount of the payment involved, this general benefit arising from price stability would be particularly important in changing payment patterns for items involving only a few dollars.

\section{ARE FLOAT INCENTIVES ECONOMICALLY SIG NIFICANT?}

How important is the choice of retail payment instrument? Consider the following thought experiment: If all 1987 household payments by check (totalling 25.8 billion) and by credit card ( 5.1 billion) had instead been carried out by debit card, and if all business and government check payments ( 21.2 billion) in that year had been executed via $\mathrm{ACH}$, those who made the payments would have lost about $\$ 41$ billion in float benefits. These "Iosses" would have been exactly balanced by $\$ 41$ billion of reduced float costs incurred by payment recipients, however, so there would have been no net gain or loss for society from this source. At the same time, the total resource cost of making retail payments in the United States would have been about $\$ 21$ billion lower. ${ }^{27}$

This estimate must be interpreted as an upper bound, since some of the social costs allocated to each payment instrument were al ready sunk as of 1987, and therefore would have been incurred even if the payment instruments weren't used. The best interpretation of this $\$ 21$ billion estimate is that it represents the efficiency gain that might have resulted if the retail payments system had developed differently than it actually did: namely, without checks and credit cards being used in retail payments at all.

Could it be that checks and credit cards appear to be "resource guzzlers" but 


\begin{tabular}{|c|c|c|c|c|c|}
\hline \multirow{2}{*}{$\begin{array}{l}\text { Payment } \\
\text { Instrument }\end{array}$} & \multicolumn{2}{|c|}{ Float Benefit at } & \multirow{2}{*}{$\begin{array}{l}\text { Average Social Cost and } \\
\text { User Prices (1995 Prices) }\end{array}$} & \multicolumn{2}{|c|}{ Total User Benefit at ${ }^{28}$} \\
\hline & 5 Percent & 2 Percent & & 5 Percent & 2 Percent \\
\hline $\mathrm{ACH}$ & 0 & 0 & $\$ 0.39$ & $-\$ 0.39$ & $-\$ 0.39$ \\
\hline Check & $\$ 0.82$ & $\$ 0.32$ & $\$ 1.06$ & $-\$ 0.24$ & $-\$ 0.74$ \\
\hline
\end{tabular}

in fact deliver correspondingly higher satisfaction to their users and recipients? In other words, could they be the "Cadillac of payment instruments," simply items on an economically efficient menu of options? If the genuine economic benefits provided by float-creating retail payment instruments exceed the social costs even when the zero-sum nature of float is netted out, then there is really no efficiency problem in the U.S. retail payments system.

A recent study concludes that checks may be popular in the U.S. not because they provide significant float benefits to check-writers but, rather, because they provide a uniquely desirable bundle of payment services not available from other payment instruments (Wells, 1996). This conclusion is based on new evidence from 1993 suggesting that checks are, in fact, even more costly than Humphrey and Berger (1990) had estimated, while float benefits from checks may have been virtually eliminated. ${ }^{29}$ Wells reasons that tiny float benefits could not possibly explain why 60 billion checks are written each year in the United States. Hence, Humphrey and Berger's emphasis on float as an incentive to use checks is "a mistaken view" (Wells, 1996, p. 3).

The implication of Wells' conclusion, if correct, is that float-intensive payment instruments such as checks may not be "over-used" in the U.S. at all. The higher resource costs associated with checks and other float-creating instruments such as credit cards should not be labelled wasteful, since genuine value is being delivered. In short, float does not reduce economic efficiency, because float is essentially irrelevant for check use.

It is probably unwise to become complacent about the efficiency of the U.S. re- tail payments system on the basis of this (or any other) individual study, however. First, the Wells (1996) and Humphrey and Berger (1990) studies are not directly comparable, so conclusions drawn from one study cannot be overturned by the other. For example, Wells uses different data sources to calculate some key components of social costs associated with checks and $\mathrm{ACH}$ (the only two payment methods examined in her study). The fact that Wells finds much higher social costs than do Humphrey and Berger may be attributable to underlying trends, or it may be due simply to differences in data-collection methods. Similarly, Wells finds much lower float benefits than do Humphrey and Berger, but the former study assumes a short-term interest rate of 3 percent (as it was during 1993), while the latter study assumes a rate of 5.775 percent, which is much closer to the average rate that has prevailed over the last ten years (and which exists today).

Even more importantly, Wells uses different definitions of social costs and float benefits than do Humphrey and Berger. For example, Wells includes payee costs (representing over 40 percent of her estimate of the social cost of checks), while Humphrey and Berger exclude them altogether. Wells excludes mail float and recipient float, while Humphrey and Berger include both (representing 37 percent and 24 percent of their estimate of float benefit, respectively). Finally, Wells assumes all checks require only one round of clearing through a financial institution, while Humphrey and Berger allow for two stages (the second stage representing 20 percent of their estimate of float benefit). It is important to note that each of these methodological differences has the effect

\footnotetext{
${ }^{28}$ Total user benefit is the float benefit at the given interest rate minus bank fees.

${ }^{29}$ Wells $(1996$, p. 5) estimates that the average social cost of a payment by check in 1993 was $\$ 2.93$ (midpoint of estimated range) while Humphrey and Berger $(1990$, p. 80, and Appendix of this article) conclude that a check payment cost society $\$ 0.79$ in 1987 (or $\$ 1.00$ in 1993 dollars). Wells estimates 1993 float benefits for checkwriters of only $\$ 0.09$, versus Humphrey and Berger's estimate of $\$ 0.83$ ( $\$ 1.04$ in 1993 dollars).
} 
of increasing Wells' estimate of social costs or decreasing her estimate of the float benefits of checks. Thus, even if both studies used identical data, Wells would find a significantly higher social cost and lower float benefit for checks than do Humphrey and Berger.

A part from these differences in data collection and methodology that prohibit direct comparisons between the Wells and Humphrey and Berger studies, there are more obvious reasons to doubt that float incentives are irrel evant for retail payment-instrument choice. As noted above, at least some consumers and businesses are aware that checks and credit cards create float, even if they do not calculate the (often trivial) benefit float confers. Surveys indicate that float incentives can and do influence payment-instrument choice for some payors at least some of the time (University of Michigan, 1995; Knudson, Walton, and Young, 1994).

The Wells study assumes that total social costs are fully internalized (taken into account) by all the relevant parties in a retail payment decision. Consequently, actual instrument choices reflect genuine benefits received..$^{30}$ In practice, of course, negotiation over the form of payment is the exception, rather than the rule. Repeated negotiation among all involved parties in the retail payment clearing and settlement chain would be extremely costly. Thus, in general, the payor exercises some choice of instrument from among a menu of alternatives provided by the payee. Since costs are incurred by others in processing the chosen payment instrument, the decision maker does not fully internalize the social costs of the payment instrument. In sum, it is not appropriate to assume, as Wells does, that all social costs associated with a particular payment instrument are fully considered-and matched by real benefits-in the choice of instrument.

Finally, the fact that consumers and businesses like certain features of a given payment instrument does not imply that all facets of that instrument contribute to (or are neutral with respect to) social wel- fare. For example, surveys reveal that consumers and businesses clearly appreciate certain features of checks and credit cards, such as convenience in record-keeping and ease of use in making payments through the mail (checks) or over the phone (credit cards). However, there is no inherent reason why float must be associated with payment instruments that provide these or other features. Humphrey, Pulley, and Vesala (1996. p. 926) point out that most retail payments in European countries and Japan are made without creating float for the payor. This does not prevent consumers and businesses in those countries from keeping records or making payments through various communication channels.

\section{CONCLUSION}

Price stability and the efficiency of the payments system are two of the Federal Reserve's most important policy goals. This article suggests that price stability could enhance the efficiency of the U.S. retail payments system because lower nominal interest rates would reduce float benefits, which affect payment users' incentives to choose particular payment instruments. Friedman (1969) pointed out the real-resource costs incurred by economic agents holding inefficiently small real money balances, by which he apparently meant cash. This article extends the argument to the full range of retail payment instruments. Instrument choice matters for economic efficiency because the most float-intensive payment instruments are typically also the most costly to produce and process, reflecting relatively long, labor-intensive clearing and settlement cycles.

Incomplete pass-through of retail payment costs to the decision makers who control instrument choice is a widespread practice that may well continue. Because this practice is the outcome of a competitive retail payments marketplace, there is little that policymakers can or should do to change it. A monetary policy geared toward price stability may therefore be an 
important practical way in which the Federal Reserve can make progress toward its goal of increasing the efficiency of the payments system.

\section{REFERENCES}

Bank for International Settlements. Payment Systems in the Group of Ten Countries, 1993.

. . . . . . Statistics on Payment Systems in the Group of Ten Countries, 1994.

. . . . . . Statistics on Payment Systems in the Group of Ten Countries, 1995.

Bauer, Paul W., and Gary D. Ferrier. "Scale Economies, Cost Efficiencies, and Technological Change in Federal Reserve Payments Processing." Joumal of Money, Credit, and Banking (November 1996 Part 2), pp. 1004-1039.

Friedman, Milton. The Optimum Quantity of Money and Other Essays. Aldine Publishing Company, 1969.

Humphrey, David B., Lawrence B. Pulley, and Jukka M. Vesala. "Cash, Paper, and Electronic Payments: A Cross-Country Analysis," Joumal of Money, Credit, and Banking (November 1996 Part 2), pp. 914-39.

_._._. and Allen N. Berger, 1990. "Market Failure and Resource Use: Economic Incentives to Use Different Payment Instruments," in David B. Humphrey, Ed., The U.S. Payment System: Efficiency, Risk and the Role of the Federal Reserve (Boston: Kluwer Academic Publishers), 45-86.

Knudson, Scott E., Jack K. Walton II, and Florence M. Young. "Businessto-Business Payments and the Role of Financial Electronic Data Interchange," Federal Reserve Bulletin 80 (April 1994), pp. 269-78.

University of Michigan. "May 1995 Survey of Consumers." Commissioned by the Federal Reserve System Future Uses of Currency Task Force.

Wells, Kirstin. "Are Checks Overused?" Quarterly Review, Federal Reserve Bank of Minneapolis (Fall 1996), pp. 2-12. 
Resource Costs and User Float Benefits of Retail Payment Instruments, 1987 *

\begin{tabular}{|c|c|c|}
\hline $\begin{array}{l}\text { Type of } \\
\text { Payment } \\
\text { Instrument }\end{array}$ & $\begin{array}{c}\text { Total Social or } \\
\text { Real Resource } \\
\text { Cost per Transaction }\end{array}$ & $\begin{array}{l}\text { User Float Benefit } \\
\text { (+ for Benefit, } \\
\text { - for Cost) }\end{array}$ \\
\hline Cash & $\$ 0.04^{a}$ & $-\$ 0.05^{b}$ \\
\hline Checks & $0.79 c$ & $0.83^{d}$ \\
\hline Credit cards & $0.88^{e}$ & $0.44^{f}$ \\
\hline $\mathrm{ACH}$ & 0.299 & $0.00^{\mathrm{h}}$ \\
\hline POS (Debit Cards) & $0.47^{i}$ & $-0.00^{j}$ \\
\hline Traveler's Checks & $1.18^{\mathrm{k}}$ & $-0.00^{\prime}$ \\
\hline Money Orders & $1.79^{m}$ & $-0.00^{n}$ \\
\hline Wire transfers & $7.33^{\circ}$ & $0.02^{p}$ \\
\hline
\end{tabular}

* Slightly abridged version of Table 2-A2 in Humphrey and Berger, 1990, pp. 80-5.

\section{a Cash}

Production costs were estimated by multiplying the number of currency notes outstanding $(11,776$ million) times an average production cost of $\$ 26$ per 1,000 notes produced at the Bureau of Engraving and Printing (giving $\$ 306$ million). The weighted average cost of coin issue is $\$ 0.0107$ per coin at the U.S. Mint for approximately 154 billion coins outstanding (giving $\$ 1,648$ million). This production cost for all currency and coin outstanding is transformed into a yearly cost as follows: Since the average $\$ 1$ bill (37 percent of currency notes outstanding) is replaced every 1.5 years, with other denominations replaced at more infrequent intervals, all currency was assumed to be replaced every two years. Coin has a very long lifetime but requires replacement over time as individual coins are lost. For our purposes, coin was assumed to be replaced every 15

years. To these replacement costs are added the cost of producing new currency and coin because of yearly growth in demand, a function of inflation and population growth. The yearly growth of cash was 8 percent between 1985 and 1987. In sum, the yearly production cost of cash is $\$ 419$ million $\{\$ 306$ million $/ 2+\$ 1,648$ million $/ 15+[(\$ 306$ million $+\$ 1,648$ million) $\times 0.08]=\$ 419$ million a year $\}$.

In accepting cash for retail sales, the payee may incur costs for all of the following: POS and accounting, theft and loss of cash, safekeeping and security, and deposit charges and fees paid to financial institutions. (See Curtin, Richard T. Payment Method Costs: Assessments by Retailers. Survey Research Center, University of Michigan, 1983). These costs, expressed as a percentage of the average cash retail transaction amount, were 2 percent (and 2.5 percent for checks). Studies have suggested that the share of retail sales paid for with cash is around 30 percent. Applying this 30 percent share and the 2 percent cost percentage to all retail sales in 1987 of $\$ 1,505$ billion yields a total payee cost of cash of $\$ 9,030$ million $(0.02 \times 0.30 \times$ $\$ 1,505$ billion). This payee cost estimate covers payee bank cash costs as well.

Payor costs of using cash cannot be reliably estimated but would include the costs of lost cash and theft along with the cost of obtaining cash from a bank. The bank costs of giving cash over the counter when checks are cashed are estimated at $\$ 1,674$ million. This estimate is derived primarily from the 1986 Functional Cost Analysis data for the 76 banks with over $\$ 200$ million in deposits. (See Board of Governors of the Federal Reserve System. Functional Cost Analysis, 1986). The smaller banks were discarded to offset the bias toward smaller banks in the Functional Cost Analysis (FCA) sample, although the difference would be negligible. The per-transaction cost of giving cash is estimated at $\$ 0.314$. The number of checks cashed per 
personal account was estimated by taking the total on-us plus transit checks cashed by the average bank per year and dividing by the average number of personal accounts per bank (for those banks reporting a separate breakout by type of account), giving 48.55 cashings per account per year. The aggregate number of personal accounts was estimated at $\mathbf{1 0 9 . 8}$ million [See Avery, Robert, Gregory Elliehausen, Arthur Kennickell, and Paul Spindt. "Changes in the Use of Transaction Accounts and Cash from 1984 to 1986," Federal Reserve Bulletin (March 1987), pp. 179-96. This article was a special unpublished computer run.] Total check-cashing costs were therefore estimated at $\$ 0.314 \times 48.55 \times 109.8 \mathrm{mil}$ lion $=\$ 1,674$ million. Federal Reserve costs in transporting and processing currency and coin, including the cost of retiring old and counterfeit currency, were $\$ 154$ million [ See Board of Governors of the Federal Reserve System. Planning and Control System Expense Report (PACS), 1987.] Thus the payee ( $\$ 9,030$ million), payor and bank (\$1,674 million), and Federal Reserve ( $\$ 154$ million) processing cost of cash is $\$ 10,858$ million.

This figure excludes the government production cost of $\$ 364$ million and the portion of processing costs borne by the Federal Reserve, \$154 million, both of which are provided free. The remaining private-sector costs are assumed passed on to cash customers through higher prices.

\section{${ }^{b}$ Cash}

The opportunity cost of holding idle coin and currency was derived from evaluating the $\$ 230$ billion in coin and currency in circulation in 1987, which is less than the $\$ 271$ billion outstanding, at the average 90-day T-bill rate in 1987 (5.775 percent), giving $\$ 13,283$ million. This figure excludes coin and currency held by the U.S. Treasury and Reserve Banks but includes idle cash balances at depository institutions. That vault cash at banks can be used to satisfy reserve requirements reflects the fact that effective reserve requirements were lowered in 1959, not the possibility that the seigniorage benefits to the government were reduced and that vault cash costs are now part of reserve requirements.

\section{'Checks}

Check production costs were estimated by taking the actual production costs per standard consumer-type check $(\$ 0.025$ cents per item) and business-type check ( \$0.05 cents per item) for a large East Coast check-printing firm and multiplying these average production costs by the volume of the types of checks written. The numbers of consumer, business, and government checks to be written are estimated, respectively, at 25.8 billion, 18.8 billion, and 2.4 billion. [See Humphrey and Berger (1990), Table 2-2, pp. 54-5.] Government checks are more like business checks and are included there. Thus the total check production cost is estimated at ( $\$ 0.025 \times$ 25.8 billion consumer checks) $+[\$ 0.05 \times$ (18.8 billion business checks +2.4 billion government checks) ] $=\$ 1,705$ million.

Check-processing costs comprised accounting and disbursement costs of business and government payors, postage (\$0.22) and envelope costs (\$0.02) for all payors (business, government, and consumers), and bank costs. The opportunity cost of consumer payers' time to write and mail checks was not included because few consumer payors actually have the opportunity of getting paid for the time saved if they do not write checks. Accounting and disbursing costs for business and government payors is estimated at $\$ 0.24$ per check or payment transaction, based on the $\$ 0.239$ per payment transaction cost for the U.S. Treasury's direct deposit program. (See Dudley, William C. A Comparison of Direct Deposit and Check Payment Costs, ed. 2, Board of Governors of the Federal Reserve System, 1983.) This excludes all postage, commercial bank, and Federal Reserve check-processing and collection expenses. Thus $\$ 0.24$ multiplied by the sum of business and government checks [ 21.2 billion items, according to Humphrey and Berger (1990) Table 2-2, pp. $54-5$ ] gives $\$ 5,088$ million in business 
and government payor costs. According to U.S. Postal Service sources, there were 153.9 billion pieces of mail handled in fiscal 1987. Earlier analyses by the University of Michigan's Survey Research Center (Household M ail Stream Study, Prepared for the Mail Classification Research Division, Rates and Classification Department, U.S. Postal Service, 1978; and Nonhousehold Mail Stream Study, Prepared for the Mail Classification Research Division, Rates and Classification Department, U.S. Postal Service, 1980) indicated that 82.5 percent of all mail originated in the nonhousehold sector, whereas 17.5 percent originated from households. Of nonhousehold-originated mail, 35 percent was bill related and typically included checks sent to pay for bills received. In contrast, 75 percent of all household-originated mail was bill related. Overall, some 42 percent $(0.75 \times 0.175+$ $0.35 \times 0.825=0.42$ ) of all mail ( 153.9 billion items) is estimated to be payment related-bills sent for collection and checks sent for payment. At $\$ 0.24$ each, the 64,638 million in payment-related items generates $\$ 15,513$ million in consumer, small business, and corporate payor stamp and envelope costs. Because almost all of these mailed items are likely to be first class mail and the number of first class items was 78.9 million in 1987, bill payment-related mail comprises 82 percent of all first class mail in this estimate.

Bank processing and transportation costs per check were estimated at $\$ 0.32$, which includes ( 1 ) costs of crediting a deposit account of $\$ 0.057$ per credit, (2) costs of processing and transporting transit items (either by the payee bank or its intermediaries) of $\$ 0.049$ per item, (3) costs of an on-us debit of $\$ 0.177$ per debt, (4) costs of handling return items of $\$ 0.012$ per item, and (5) the cost of returning canceled checks to account holders of $\$ 0.029$ per check. These estimates were based primarily on data from the 1986 Functional Cost Analysis data for the 76 banks with more than $\$ 200$ million in deposits. (See Board of Governors of the Federal Reserve System. Functional Cost Analysis, 1986.) The smaller banks were discarded to offset the bias toward smaller banks in the FCA sample, although the estimates would not be substantially different if these smaller banks were included. The estimate in (1) was determined by dividing the cost of handling a deposit $(\$ 0.3627)$ by the number of checks per average deposit (6.386). The estimate in (2) was determined by multiplying the cost of a transit check deposited ( $\$ 0.0975)$ by the proportion of total handlings accounted for by transit items (0.507). (N ote that this proportion is less than the proportion of transit checks overall, because all transit checks are also handled as on-us items by other banks.) The estimate in (3) is simply the FCA's estimate of the cost of an on-us debit. The estimate in (4) was determined by using data from a return item study by J. D. Carreker and Associates. (See Carreker, J. D., and Associates, Inc. Return Item Study: Final Report. Prepared for the Bank Administration Institute, 1985.) It was estimated that 350 million out of about 40 billion items in 1985 were returned-a ratio of 0.00875 . The estimated costs to reject the item are $\$ 0.71$, and the estimated cost to send the item each step backward through the endorsement chain is $\$ 0.43$. We assume that the $\$ 0.43$ also applies to returning the item to the payee. The average return-item cost of $\$ 0.012$ was therefore determined to be $(0.00875)$ $\times\{\$ 0.71+\$ 0.43+[\$ 0.43 \times 0.507]\}$, where 0.507 is the transit-handling proportion discussed previously. The estimate in (5) was determined by taking the check safekeeping savings of $\$ 7$ per account per year (that is, the savings from not returning canceled checks to payors) reported by Valley National Bank. (See Wall Street Journal. "Canceled Checks Are Destroyed at Some Banks, Producing Savings." February 21,1985 p. 1.) and dividing by the number of checks written per account per year (237.28). Thus bank processing costs are $\$ 0.32 \times 47$ billion checks $=\$ 15,040$ million. Together, the business and government payor accounting and disbursing costs ( $\$ 5,088$ million), the mailing costs for all payors ( $\$ 15,513$ million), and the bank costs just derived total $\$ 35,641$ mil- 
lion in check-processing costs. Bank costs will include Federal Reserve check-processing and transportation costs.

\section{${ }^{d}$ Check}

The total value of check float in 1987 is estimated at $\$ 39.1$ billion. [See Humphrey and Berger (1990) Table 2-2, pp. 54-5, note $c$ ]. Dividing by 47 billion checks written gives a per-item float benefit of $\$ 0.83$. The cost of holding funds earning little or no interest in a checking account is assumed to be a soft-dollar payment for services and is therefore implicitly included under production and processing costs rather than float costs.

\section{eCredit Cards}

Credit card production costs- which include the costs of issuing the cards, maintaining accounts, and paying merchants- on average equal ed the cost of float. (See Bank Administration Institute. Banking Issues and Innovations, 1985. This was referenced in American Banker, April 9, 1985, p. 16.) Production costs are presumed equal to the cost of float today as well ( $\$ 2,257$ million). Retail or merchant processing costs were $\$ 0.44$ per credit card transaction, giving a total processing cost of $\$ 2,249$ million [from 5,111 million card transactions in Humphrey and Berger (1990) Table 2-A1, pp. 77-9, multiplied by $\$ 0.44$, from Board of Governors of the Federal Reserve System. Credit Cards in the U.S. Economy, 1983, p. 43]. Thus the total social (user) costs of credit card transactions are estimated at $\$ 4,506$ million ( $\$ 2,249$ million) with a unit cost estimate of $\$ 0.88(\$ 0.44)$ per transaction.

\section{${ }^{f}$ Credit Cards}

According to a Bank Administration Institute study (Banking Issues and Innovations, 1985), bank credit card transactions are outstanding an average of 45 days. Thus total credit card float costs are estimated at $\$ 2,257$ million. [This estimate is based on a figure of $\$ 317$ billion in yearly charge volume in Humphrey and Berger (1990) Table
2-A1, pp. 77-9, divided by 365 days, multiplied by the 45 days a transaction is outstanding, multiplied by the 90 -day Treasury bill rate of 0.05775 .]

\section{${ }^{9} \mathrm{ACH}$}

Payor ACH costs are estimated to be $\$ 0.18$ per $\mathrm{ACH}$ item, based on the government's direct deposit ACH costs. (See Dudley, William C. A Comparison of Direct Deposit and Check Payment Costs, ed. 2. Board of Governors of the Federal Reserve System, 1983.) Applying this origination cost to the total volume of $\mathrm{ACH}$ items originated [936 million items in Humphrey and Berger (1990) Table 2-A1, pp. 77-9] gives $\$ 168$ million as an estimate of government and business payor costs. Payee and bank ACH costs were derived by multiplying the 1987 weighted average per item commercial bank price for $\mathrm{ACH}$ ( $\$ 0.089$, from Trans Data Corporation. 1988 Bank Pricing Program, 1988, p. 42) by $1987 \mathrm{ACH}$ item volume (936 million), giving $\$ 83$ million. This includes per-item fees, tape-handling costs, and other $\mathrm{ACH}$ charges. The commercial bank prices used included all Federal Reserve costs [ $\$ 71$ million, from Board of Governors of the Federal Reserve System. Planning and Control System Expense Report (PACS), 1987, including a 16 percent PSAF ]. Last, some bills paid through an $\mathrm{ACH}$ are first mailed to payors as a notification before debiting a customer's account. These costs ( $\$ 0.22$ for postage plus $\$ 0.02$ for an envelope) are assumed to apply to 20 percent of ACH commercial volume, which is around one-half of total $\mathrm{ACH}$ volume of 936 million. Thus mail costs of $\$ 22$ million ( $\$ 22$ million $=$ $\$ 0.24 \times 0.10 \times 936$ million) are added to $\mathrm{ACH}$ costs of $\$ 251$ million, giving total $\mathrm{ACH}$ processing costs of $\$ 273$ million.

\section{${ }^{h} \mathrm{ACH}$}

$\mathrm{ACH}$ debits do create some float, like checks, but there is no float associated with $\mathrm{ACH}$ credits, which are like European giro payments. ACH debit float, evaluated at the 90-day Treasury bill rate cited previously, gives less than $\$ 1$ million in float value in 
1987. Wire transfer also can create some float and fluctuates between debit and credit float [none for Clearinghouse Interbank Payments System (CHIPS) ]. Over 1987, wire transfer debit float valued at less than $\$ 2$ million was created. Debit float is a user benefit; credit float is a user cost.

\section{iPOS (Debit cards)}

Some POS networks use a direct debit to an account (like an ATM withdrawal or bill payment with a unit cost of $\$ 0.66$ ). 0 ther networks are configured to work more slowly through an $\mathrm{ACH}$, which has a unit cost of $\$ 0.27$. Lacking strong evidence on the real cost of POS, we assumed that it is likely to fall between that for an ATM direct debit and an ACH transfer. The simple average of these two unit costs was $\$ 0.47$, which was used to approximate the cost of a POS transaction.

\section{iPOS (Debit cards).}

There is no float associated with POS transactions (except for those functioned through an $\mathrm{ACH}$, but the value of this float is small), so the user costs and the social costs $(\$ 0.47 \times 55$ million POS transactions $=\$ 26$ million) are the same.

\section{kTraveler's Checks}

Production, processing, and operating costs for traveler's checks are proprietary. Thus it was assumed that revenues associated with issuing traveler's checks equaled the costs involved. Generally, an issuing fee of 1 percent of the face value of the travel er's check is assessed, yielding a revenue flow of $\$ 470$ million [from $0.01 \mathrm{mul}$ tiplied by $\$ 47$ billion, in Humphrey and Berger (1990) Table 2-A1, pp. 77-9]. More revenue for the issuer is obtained from float because it is estimated that the average traveler's check is outstanding for 70 days. (See Penzer, Michael L. "The Nature and Size of Money Order and Traveler's Check Markets in California and the $\mathrm{Na}$ tion." Economic and Financial Information Division, California State Banking
Department, 1978, p. 32. Penzer estimated that a traveler's check was outstanding for an average of 57 days in 1976.) Float revenues to the issuer are $\$ 525$ million [from 0.05775 - the 90 -day Treasury bill rate in 1987-multiplied by $\$ 7.0$ billion and divided by $(I-0.23)]$, which was the average daily value of outstanding nonbank traveler's checks. [See Humphrey and Berger (1990) Table 2-A1, pp. 77-9, note d, adjusted upwards to account for bank traveler's checks.] Thus the costs of issuing and paying traveler's checks, which would also cover the expense of funding lost checks, is $\$ 525$ million plus $\$ 470$ million for a total of $\$ 995$ million. The retail cost of handling and processing traveler's checks is assumed to be equal to that for cash of $\$ 0.45$ per transaction (Board of Governors of the Federal Reserve System, 1983, Credit Cards in the U.S. Economy, Washington, D.C., p. 43), which yields a cost of $\$ 0.45$ times 1,345 million transactions (Humphrey and Berger, 1990, Table 2-A1, pp. 77-9) $=\$ 609$ million.

\section{'Traveler's Checks}

Though there is float associated with traveler's checks ( $\$ 525$ million in float divided by 1,345 million transactions $=\$ 0.39$ in float cost per traveler's check), we have assumed that all float revenues in fact cover operating costs, so float in the same sense as check float, or the opportunity cost of holding idle funds, in the same sense as applied to the issuance of cash by the government, does not exist. Put differently, traveler's check float is not the same thing as a redistribution of income between payor and payee but rather an alternative method of covering operating expenses for the issuer of the traveler's check. Because this is a reasonably competitive industry, we have assumed that there is no monopoly power on the part of the issuer to obtain above-normal profits (such a situation does not apply to the issuance of currency by the government). In sum, the user and social unit costs of a traveler's check are the same at $\$ 1.18$ per transaction [ $\$ 995$ million plus $\$ 609$ million) divided by 1,345 million transactions]. 


\section{mMoney Orders}

Federal Reserve cost in processing 146 million postal money orders in 1987 was $\$ 2.8$ million [ direct and allocated costs plus overhead (39 percent of total activity costs), from Board of Governors of the Federal Reserve System. Planning and Control System Expense Report (PACS), 1987], or $\$ 0.019$ per money order. This unit cost figure was applied to the 811 million money orders estimated to have been used in 1987 [Humphrey and Berger (1990) Table 2-A1, pp. 77-9], giving \$15 million. Merchant or receiver processing costs were assumed to equal those reported for checks at a sample of retail stores: of $\$ 0.50$ per item for a total merchant processing cost of (811 million money orders) $\times(\$ 0.50)=\$ 406$ million. (See Board of Governors of the Federal Reserve System. Credit Cards in the U.S. Economy, 1983, p. 43.) It was assumed that one-half of all money orders are mailed by the user, giving an extra user cost of $\$ 97$ million [from per-item postage cost ( $\$ 0.22)$ plus per-envelope cost ( $\$ 0.02)$ multiplied by 0.5 and then multiplied by 811 million items = $\$ 97$ million]. This assumption is supported in a survey of money order users in California by Pierce, who found that the payment of utility and other monthly bills plus sending money to relatives or friends accounts for almost two-thirds of the responses as to why money orders were used. (See Pierce, James L. "The U sers of M oney Orders," University of CaliforniaBerkeley, 1977. Appendix Table A-3, p. 8.) Total money order processing costs are thus estimated at \$518 million. Money order production costs, including all costs of distributing them to users plus the costs of redemption, are taken from postal money order fiscal year data for 1984 (and thus will not match exactly with the volume and value figures for postal money orders processed by the Federal Reserve in calendar year 1987). The directly allocated production costs for postal money orders were $\$ 0.79$ per item ( $\$ 112$ million in directly allocated cost divided by 142 million items in fiscal year 1987 from U.S.
Postal Service, Costs and Revenue Analysis Report, 1987). Revenues, however, were $\$ 1.15$ per item ( $\$ 148$ million from fees plus $\$ 16$ million from float, giving $\$ 164$ million total, divided by 142 million items). Revenues from money orders (\$164 million) in excess of directly allocated costs ( $\$ 112$ million) are allocated to Postal Service overhead for all services offered. These overhead costs are viewed as joint costs and are reallocated back to the individual services according to certain criteria, one of which is the value of the service to the user (Ramsey pricing). Thus it is impossible to determine whether postal money order revenues cover all costs or if excess profits (or losses) are being incurred and cross-subsidization exists. Penzer has noted that use of postal money orders peaked in 1952 and subsequently lost market share to bank-issued money orders and private firms. (See Penzer, Michael L. "The Nature and Size of Money Order and Travel er's Check Markets in California and the Nation." Economic and Financial Information Division, California State Banking Department, 1978, p. 6.) This implies that postal money orders face a competitive market and, if anything, may be cross-subsidized rather than be used to cross-subsidize other postal services. As a result, we assume here that all postal money order revenues are used to cover all costs, even though it is likely that costs may exceed total revenues by some unknown amount. This implies that the fully allocated cost of a postal money order is at least $\$ 1.15$ per item, and this figure is used to approximate the unknown production cost of all money orders. Thus total production costs of all money orders is estimated at $\$ 1.15 \times$ (811 million items) $=\$ 933$ million, for $a$ total social cost of $\$ 1,451$ million. Total user costs are the same because total money order float costs of $\$ 89$ million (from $\$ 0.11$ multiplied by 811 million items) are presumed fully used to cover real resource costs and represent an alternative charging method rather than a transfer payment. 


\section{"Money Orders}

Money orders are estimated to be outstanding between 5 and 11 days. (See Penzer, Michael L. "The Nature and Size of Money Order and Traveler's Check Markets in California and the Nation." Economic and Financial Information Division, California State Banking Department, 1978, p. 8.) Taking the midpoint ( 8 days) generates an estimated float benefit of $\$ 16$ million for postal money orders ( $\$ 16$ million $=\$ 12.511$ billion annual value of postal money orders outstanding multiplied by $8 / 365$ of a year multiplied by an interest rate of 0.05775 ).

\section{-Wire Transfers}

Wire transfer volume in Humphrey and Berger (1990) Table 2-A, pp. 77-9 (84 million) was multiplied by a weighted average commercial bank charge for wire transfers (\$7.33, from Trans Data Corporation. 1988 Bank Pricing Program, 1988, p. 72) to give the total cost of wire transfers ( $\$ 616$ million). The Federal Reserve wire transfer cost components [from Board of Governors of the Federal Reserve System. Planning and Control System Expense Report (PACS), 1987] and the PSAF were $\$ 66$ million, which was assumed to be fully passed to final users in these bank fees.

\section{${ }^{p W}$ ire Transfers}

Wire transfer also can create some float, which fluctuates between debit and credit float (none for CHIPS). Over 1987, wire transfer debit float valued at less than $\$ 2$ million was created. Debit float is a user benefit; credit float is a user cost. 